\title{
THE IMPLEMENTATION OF DISTANCE LEARNING ON EARLY CHILDHOOD EDUCATION DURING NEW NORMAL ERA OF COVID-19
}

\author{
Luluk Musthofiyah \\ Institut Agama Islam Negeri Pekalongan, Indonesia \\ E-mail: luluk.musthofia@gmail.com \\ Sopiah \\ Institut Agama Islam Negeri Pekalongan, Indonesia \\ E-mail:sopiab@iainpekalongan.ac.id \\ Hendri Hermawan Adinugraha* \\ Institut Agama Islam Negeri Pekalongan, Indonesia \\ E-mail:bendri.hermawan@iainpekalongan.ac.id

\section{(c) (1) ()} \\ (C2021 by the authors. Submitted for possible open access publication under the terms and conditions \\ of the Creative Commons Attribution (CC-BY-SA) license (https://creativecommons.org/licenses/by-sa/4.0/) \\ do DOI : http://dx.doi.ong/10.30983/educative.v6i1.4112 \\ *Corresponding author \\ Submission : February 9, 2021 \\ Revised : June 7, 2021 \\ Published: June 30, 2021
}

\begin{abstract}
The purposes of this study are to describe the implementation and to find out the supporting and inbibiting factors of distance learning for early childhood in the new normal era of Covid-19 at ABA Penconga $n$ Kindergarten. Method that used in this study is field research with a qualitative approach, as for data collection techniques used triangulation, and data analysis technique used an interactive model. The results showed that the implementation of distance learning for early childhood at $A B A$ Pencongan Kindergarten was implemented through the Whatsapp class group. The learning implementation was carried out remotely every Monday, teachers provided weekly lesson preparation plans and learning videos. As for learning evaluation teachers used the work, checklists, and anecdotal notes. The work results are in the form of collaging task, coloring and drawing, folding and cutting, and building blocks. Several factors that support this learning process are adequate school facilities, the skills of educators in using media or applications, good psychological condition of students, and their parents' free-time to assist and guide students to learn at home. On the other hand, the inbibiting factors are school financial constraints, difficulties for teachers in managing learning activities, students being forced to make academic adjustments by limiting social interaction, busy activity of students' parent, and additional costs for buying internet data packages.
\end{abstract}

Keywords: Covid-19, early childhood education, and distance education.

\section{Abstrak}

Tujuan penelitian ini untuk mendiskripsikan implementasi dan untuk mengetabui faktor pendukung dan penghambat pembelajaran jarak jaub anak usia dini pada era new normal Covid-19 di TK ABA Pencongan. Metode yang digunakan adalah penelitian lapangan dengan pendekatan kualitatif. Teknik. pengumpulan data menggunakan observasi, wawancara dan dokumentasi. Teknik analisis data menggunakan model interaktif. Hasil penelitian menunjuk.kan bahwa implementasi pembelajaran jarak jauh anak usia dini pada era new normal Covid-19 di TK ABA Pencongan melalui grup Whatsapp kelas. Pelaksanaan pembelajaran dilakukan secara jarak jaub setiap hari senin tenaga pendidik memberikan Rencana Persiapan Pelajaran Mingguan dan video pembelajaran sekaligus mengabsensi kehadiran. Evaluasi pembelajaran menggunakan hasil karya, checklist, dan catatan anekdot. Hasil karya berupa kolase, mewarnai dan menggambar, melipat dan menggunting, dan hasil karya bangunan balok. Faktor yang mendukung dalam proses pembelajaran ini ialah fasilitas sekolah yang memadai, keterampilan tenaga pendidik menggunakan media atau aplikasi dalam pengajaran yang mumpuni, kondisi psikis murid yang baik, dan keluangan waktu orang tua untuk mendampingi sekaligus membimbing pembelajaran anak murid di rumah. Sedangkan faktor penghambatnya yaitu kendala finansial sekolah, kesulitan para guru dalam mengelola kegiatan pembelajaran, murid dipaksa melakukan penyesuaian akademik dengan membatasi interaksi sosial, dan kesibukan beberapa orang tua, dan biaya tambahan untuk membeli paket data internet.

Kata Kunci: Covid-19, pendidikan anak usia dini, dan pembelajaran jarak. jauh. 


\section{Introduction}

Currently, the world was hit by the corona virus or commonly known as Covid-19 (Corona Virus Disease-19). The case of the corona virus began in December 2019. The virus is linked to an animal market in Wuhan, China, which sells all types of animal meat, including those that cannot be eaten. The corona virus is believed to be carried by bats, snakes, and various other exotic animals eaten by humans that are considered carriers of Covid-19. ${ }^{1}$

The threat of a pandemic is increasing when various cases show human-to-human transmission without any history of traveling to closed markets. At the end of January 2020, the World Health Organization established a Global Emergency status in Corona virus cases. ${ }^{2}$ The reason is, the virus continues to spread rapidly to areas that are far from the center of the Covid-19 outbreak. ${ }^{3}$

The effect of the corona virus which initially had a significant impact on the economy is now also being faced by the world of education. ${ }^{4}$ The central and local governments have issued policies to close all educational institutions. ${ }^{5}$ This action was needed to minimize the spread of the corona virus. Many countries, including Indonesia, have closed all educational activities, so the government and related institutions must

${ }^{1}$ Kemenkes RI, ‘Corona Virus Disease 2019', Peraturan Menteri Kesebatan Republik Indonesia, 2020.

2 Goolam Mohamedbhai, 'COVID-19: What Consequences for Higher Education', University World News, 2020.

${ }^{3}$ Diah Handayani, 'Penyakit Virus Corona 2019', Jurnal Respirologi Indonesia, 2020.

4 City Trahern Jones of Pediatric Infectious Diseases Instructor of Pediatrics of Utah Health Lake and Francisco Danielle Nahal Resident Physician Medical Center, 'Beating the Pandemic: What Emergency Providers Should Know About COVID19', Pediatric Emergency Medicine Reports, 2020.

5 Trahern Jones of Pediatric Infectious Diseases Instructor of Pediatrics of Utah Health Lake and Danielle Nahal Resident Physician Medical Center. provide other ways of education for students who cannot study at educational institutions. ${ }^{6}$ Then, the Ministry of Education and Culture of the Republic of Indonesia issued circular letter number 4 of 2020 which covers the implementation of education policies during the Covid-19 emergency. Regarding the widespread of the Covid-19 disease, the physical and mental health of teachers, students, school principals, and all school members become the main considerations in implementing an education policy. Related to this, the learning process is carried out with provisions through Distance education. ${ }^{7}$

Distance education refers to a learning process that separates students from teaching staff. This is based on Article 1 of the Law of the Republic of Indonesia Number 20 of 2003 concerning the National Education System of the Republic of Indonesia, about the various learning resources for learning through communication technology, information, and other media. ${ }^{8}$ If you look at the current situation, the implementation of Distance education is indeed relevant. According to Article 31 Paragraph 2 of Law Number 20 the Year 2003 of the Republic of Indonesia, the function of distance education can provide educational services for community groups who cannot attend face-to-face or regular education. ${ }^{9}$

\footnotetext{
6 Agus Purwanto and others, 'Universitas Muhammadiyah Enrekang Studi Eksploratif Dampak Pandemi Covid-19 Terhadap Proses Pembelajaran Online Di Sekolah Dasar', EduPsyCouns: Journal of Education, Psychology and Counseling, 2020.

Nadiem Anwar Makarim, 'Pelaksanaan Kebijakan Pendidikan Dalam Masa Darurat Penyebaran Covid -19', Surat Edaran Permendikbud No 4 Tabun 2020, 2020.

${ }^{8}$ Asep Suraya, Hendri Hermawan, and Iain Pekalongan, 'Progressive Education in Indonesia: Insight from Soedjatmoko Thought', 7.2 (2020), 113-21 <https://doi.org/10.32923/tarbawy.v7i2.1410>.

9 'Undang Undang Republik Indonesia Nomor 20 Tahun 2003', Kemenristekdikti, 2003.
} 
Learning is an active interaction between students and teachers where teachers provide students with learning materials. Learning is also an effort to improve the proficiency of learning materials. ${ }^{10}$ Learning as an activity process consists of three stages, such as the planning stage, the implementation stage, and the evaluation stage. ${ }^{11}$ The three stages will be discussed as follows: a) The Learning Planning Stage, the lesson plan is any plan made by teachers to realize an activity in the learning process, how to carefully organize each activity to achieve the learning objectives that need to be achieved. What is the content of the activity (material), what methods will be used, and evaluated. Kindergarten learning plans include annual planning, semester planning, weekly implementation of program planning, and daily implementation of program planning; ${ }^{12}$ b) The Learning Process Stage, the learning process is an activity carried out by two parties, namely teachers as facilitators and students as learners who involve intermediaries to convey messages in the form of knowledge, skills, and attitudes of positive values. In conveying the message, an intermediary is needed so that the value and transfer of knowledge can be achieved precisely on the target. Those intermediaries are media and learning resources that are very supportive and can influence the success of this learning. The learning process that occurs both inside and outside the classroom is a continuous process so that it can change the abilities of students; ${ }^{13}$ c) Learning Evaluation

${ }^{10}$ Harold Pashler and others, 'Learning Styles Concepts and Evidence', Psychological Science in the Public Interest, Supplement,

2008

$<$ https://doi.org/10.1111/j.1539-6053.2009.01038.x>.

11 Pashler and others.

12 D. Suryana, 'Pendidikan Anak Usia Dini Stimulasi Dan Aspek Perkembangan Anak.', Kencana., 2016.

${ }^{13}$ Mustofa Abi Hamid, Lely Yuliawati, and Didik Aribowo, 'Feasibility of Electromechanical Basic Work E-Module as a New Learning Media for Vocational
Stage. Evaluation is a systematic process of collecting, analyzing, interpreting, and making decisions about the information collected. The purpose of evaluation in learning includes assessing the achievement of goals and making the basic evaluation for curriculum change. ${ }^{14}$

Some of the research gaps explicitly say that research on the impact of Covid-19 on online access to "Study from Home" able to describe as follows: The majority of parents are information literate learning from home; ${ }^{15}$. Offline learning methods such as books and student worksheets while studying from home are preferred over online learning methods; ${ }^{16}$ Children are given many tasks by the teacher when online learning; ${ }^{17}$ The influence of parents' work and education on accessing online learning; ${ }^{18}$ Parent's educational background and economics tend to contribute to the process of online learning access; ${ }^{19}$

Students', Journal of Education and Learning (EduLearn), 2020

<https://doi.org/10.11591/edulearn.v14i2.15923>.

${ }^{14}$ Selfi Lailiyatul Iftitah, 'Strategi Pengembangan Nilai-Nilai Keagamaan Pada Anak Usia Dini Di TK Islamic Center Surabaya', KINDERGARTEN: Journal of Islamic Early Childhood Education, 2020 <https://doi.org/10.24014/kjiece.v3i1.9407>.

15 Erlina Neni Indriyani, 'Pengaruh Korelasi Peran Orang Tua Dan Guru Berbasis Online Di Rumah Dalam Pembelajaran Pendidikan Agama Islam', Jurnal Pendidikan Guru, $\quad 2.1 \quad$ (2021) <https://doi.org/10.47783/jurpendigu.v2i1.185>.

${ }^{16}$ Hermanto, Ni Gusti Made Rai, and Arfan Fahmi, 'Students' Opinions about Studying from Home during the COVID-19 Pandemic in Indonesia', Cypriot Journal of Educational Sciences, 16.2 (2021) <https://doi.org/10.18844/CJES.V16I2.5627>.

17 Bogum Yoon, 'English Language Learners' Language and Literacy Development: A Brief Synopsis of Major Theoretical Orientations for Middle School Teachers', Middle School Journal, 52.1 (2021) <https://doi.org/10.1080/00940771.2020.1840270>.

$18 \mathrm{Ji}$ Young Kim and Daniel M. Fienup, 'Increasing Access to Online Learning for Students With Disabilities During the Covid-19 Pandemic', Journal of Special Education, 2021 <https://doi.org/10.1177/0022466921998067>.

19 Amy J. Catalano, Bruce Torff, and Kevin S. Anderson, 'Transitioning to Online Learning during the COVID-19 Pandemic: Differences in Access and 
In addition to the aspects of work and education, it was also found that there were differences in the contribution of parents to guide them while they were studying from home. ${ }^{20}$ Although home education is the responsibility of both parents, ${ }^{21}$ in fact, mothers allocate more time or accompany children more than fathers.

On the other hand, playing is an effort to get pleasure and soul satisfaction from every activity undertaken, whether using game tools or not. Whatever the activity, as long as it brings joy or happiness to children in early childhood, it can be called "a playing activity" that can develop children's potential. ${ }^{22}$ In playing activities children should be supported by three types of play activities such as sensorimotor, role, and development; several playing materials, through playing children can interact socially with their friends. ${ }^{23}$ Children are always quick to turn their attention to other activities unless they are fun and varied for children. ${ }^{24}$

Now distance education can be carried out between teachers and students in different

Participation among Students in Disadvantaged School Districts', International Journal of Information and Learning Technology, $\quad 38.2 \quad$ (2021) <https://doi.org/10.1108/IJILT-06-2020-0111>.

${ }^{20}$ Joseph Friedman and others, 'U.S. Children "Learning Online" during Covid-19 without the Internet or a Computer: Visualizing the Gradient by Race/Ethnicity and Parental Educational Attainment', Socius, (2021) < https://doi.org/10.1177/2378023121992607>.

21 'Revitalization of Education for Children in Indonesian Families During the Covid-19 Pandemic', Illkögretim Online, $20.3 \quad$ (2021) $<$ https://doi.org/10.17051/ilkonline.2021.03.48>.

22 M Fadlillah, Bermain \& Permainan Anak Usia Dini, Pranadamedia Grub, 2019.

23 Beryana Evridawati, Yufiarti, and Elindra Yetti, 'The Cognitive Style and Attachment on Early Childhood Speech Skills', JPUD - Jurnal Pendidikan Usia Dini, 2020 <https://doi.org/10.21009/jpud.141.03>.

24 Tri Utami, 'Penanaman Kompetensi Inti Melalui Pendekatan Saintifik Di PAUD Terpadu AnNur', Yaa Bunayya (Jurnal Pendidikan Anak Usia Dini), 2017. places, thus simplifying the learning process. ${ }^{25}$ Meanwhile, defines distance education as a system and process that connects students with learning resources in the same electronic space. ${ }^{26}$ So, it can be concluded from the above understanding that distance education is anything that can present information and knowledge in the interaction between teachers and students without meeting. Distance education is carried out in an electronic room that requires a network connection so that students can receive learning without coming to school, to support the learning process. ${ }^{27}$ Thus it can be concluded that with the elements of distance education, teachers can deliver learning materials so that students can get learning information even if they don't meet directly. With the material that has been provided by teachers, it is hoped that students can learn at home ${ }^{28}$

The essence of early childhood is a developmental process because the changes experienced by every human being lasts a lifetime, from conception to death. Early childhood is an individual that is different, unique, and has any characteristics according to their age stages. Early childhood is usually

25 M. Ghofar Rohman and Purnomo Hadi Susilo, 'Peran Guru dalam Penggunaan Media Pembelajaran Berbasis Teknologi Informasi dan Komunikasi (TIK) Studi Kasus di Tk Muslimat Nu Maslakul Huda', Jurnal Reforma, 2019 <https://doi.org/10.30736/rfma.v8i1.140>.

26 Ahmad Munir Saifulloh and Mohammad Darwis, 'Manajemen Pembelajaran Dalam Meningkatkan Efektivitas Proses Belajar Mengajar Di Masa Pandemi Covid-19', Bidayatuna: Jurnal Pendidikan Guru Mandrasah Ibtidaiyah, 2020 <https://doi.org/10.36835/bidayatuna.v3i2.638>.

27 Vandana Singh and Alexander Thurman, 'How Many Ways Can We Define Online Learning? A Systematic Literature Review of Definitions of Online Learning (1988-2018)', American Journal of Distance Education, 2019

<https://doi.org/10.1080/08923647.2019.1663082>.

28 Roman Andrianto Pangondian, Paulus Insap Santosa, and Eko Nugroho, 'Faktor - Faktor Yang Mempengaruhi Kesuksesan Pembelajaran Daring Dalam Revolusi Industri 4.0', Sainteks 2019, 2019. 
referred to as pre-school children, they are in a sensitive development period and psychological functions are mature and can respond to various stimuli in their environment. ${ }^{29}$ The best conditions for children to develop and learn are in a community that respects them, meets their physical needs and also safe in physical and psychological aspects. ${ }^{30}$

Distance education is a new teaching method that uses electronic devices, especially the internet connection for learning. ${ }^{31}$ Distance education relies completely on the internet. Distance education is one of the common forms of learning that can be converted into digital forms via the internet. ${ }^{32}$ Distance education is the only medium to convey information between teachers and students in the case of the Covid-19 emergency. ${ }^{33}$

For early childhood teachers, ideally, learning held in PAUD institutions is in accordance with the principles in general that have been carried out so far, namely through face-to-face learning, learning through playing, and in fun things. ${ }^{34}$ However, in early

${ }^{29}$ E. Mulyasa and Mulyasa.H.E., Manajemen Paud, Manajemen PAUD, 2014.

${ }^{30}$ William M. Wind, Richard M. Schwend, and Judy Larson, 'Sports for the Physically Challenged Child.', The Journal of the American Academy of Orthopaedic Surgeons, $2004<$ https://doi.org/10.5435/00124635200403000-00008>.

31 Kimberly C. Harper, Kuanchin Chen, and David C. Yen, 'Distance Learning, Virtual Classrooms, and Teaching Pedagogy in the Internet Environment', Technology in Society, 2004 <https://doi.org/10.1016/j.techsoc.2004.08.002>; Kuntum Annisa Imania and Siti Khusnul Bariah, 'Rancangan Pengembangan Instrumen Penilaian Pembelajaran Berbasis Daring', Jurnal Petik, 2019 <https://doi.org/10.31980/jpetik.v5i1.445>.

${ }^{32}$ George Ngwacho Areba, 'Covid-19 Pandemic Impact on Kenyan Education Sector: Learner Challenges and Mitigations', Journal of Research Innovation and Implications in Education, 2020.

33 Imania and Bariah.

34 Alisa Alfina and Rosyida Nurul Anwar, 'Manajemen Sekolah Ramah Anak PAUD Inklusi', Al- childhood distance education, which in fact, learners in a period of growth and development who gain concrete learning experiences through playing, now have to do learning activities from home with their parents. ${ }^{35}$

Early childhood distance education patterns in the new normal Covid-19 situation, ${ }^{36}$ namely students learning from home. 37 Learning from home activities for early childhood can be a turning point for the role of the family, especially parents who play a very important role in children's development because parents interact the most with children. ${ }^{38}$ Early childhood education during this period requires support and cooperation between teachers and parents. ${ }^{39}$

Aisyiyah Bustanul Athfal Kindergarten (ABA) Pencongan is a superior school which is located at Wiradesa District, Pekalongan Regency. According to the observations of researchers, ABA Pencongan Kindergarten is one of the institutions that implements distance education for early childhood in the new normal era of Covid-19. This is a learning solution in the new normal of the Covid-19 era with the hope that students continue to learn even in the midst of the Covid-19 outbreak. In this case, teachers and students

Tanz̧im: Jurnal Manajemen Pendidikan Islam, 2020 <https://doi.org/10.33650/al-tanzim.v4i1.975>.

35 Renti Oktaria and Purwanto Putra, 'Pendidikan Anak dalam Keluarga Sebagai Strategi Pendidikan Anak Usia Dini Saat Pandemi Covid-19', Jurnal Ilmiah Pesona PAUD, 2020 $<$ https://doi.org/10.24036/108806>.

36 Jinyoung Kim, 'Learning and Teaching Online During Covid-19: Experiences of Student Teachers in an Early Childhood Education Practicum', International Journal of Early Childhood, 2020 <https://doi.org/10.1007/s13158-020-00272-6>.

${ }^{37} \mathrm{Kim}$.

${ }^{38}$ Suzanne L. Krogh and others, 'Inquiry-Based Learning', in The Early Childhood Curriculum, 2020 <https://doi.org/10.4324/9780429280764-6>.

39 Ilyas Rifa'i and others, 'Dampak Dan Pencegahan Wabah Covid-19: Perspektif Sains Dan Islam', Jurnal Pendidikan, 2020. 
do not need to meet in person, everyone can carry out their duties at home using the WhatsApp application. ${ }^{40}$ However, early childhood children really need the role of adults or parents. ${ }^{41}$

Based on the background of the problems that occur, the aim of the research is to describe the implementation of distance education for early childhood in the new normal era of Covid-19 in ABA Pencongan Kindergarten Pencongan, Wiradesa District, Pekalongan and to explain the supporting and inhibiting factors for implementing Distance education for early childhood in new normal Covid-19 era at ABA Pencongan Kindergarten, Wiradesa District, Pekalongan.

Practically the contribution and benefits of this research for schools, the results of this study are expected to contribute to the implementation of distance learning for early childhood in the new normal era of Covid-19 in ABA Pencongan Kindergarten; For educators to increase knowledge and insight in the implementation of distance learning for early childhood in the new normal era of Covid-19 at ABA Pencongan Kindergarten; Finally, the usefulness of this research is expected to provide scientific contributions in the realm of early childhood education.

\section{Method}

This type of research was used field research with a qualitative approach. The research conducted by the author took the location at ABA Pencongan Kindergarten, Wiradesa District, Pekalongan Regency Jl. Merpati Gang. IV Ex. Bener Wiradesa,

40 Muhammad Awin Alaby, 'Media Sosial Whatsapp Sebagai Media Pembelajaran Jarak Jauh Mata Kuliah Ilmu Sosial Budaya Dasar (ISBD)', Ganaya: Jurnal Ilmu Sosial Dan Humaniora, 2020.

41 Adinda Icha Rohmadani, 'Dampak Covid 19 Terhadap Cara Berpikir Dalam Pembelajaran Daring: Studi Kasus Di Yogyakarta', Edification Journal, 2020 <https://doi.org/10.37092/ej.v3i1.224>.
Pekalongan, Central Java. Because the school is the largest PAUD school in the sub-district and has implemented online learning

The research was carried out in the first semester of the September 2020/2021 academic year. There are two sources of data in this research, primary and secondary data sources. Data collection techniques using observation, interviews, and documentation. ${ }^{42}$ Observations were carried out by visiting and following the learning process at school by teachers and the student learning process at home accompanied by parents, by visiting several of their homes as the implementation of this observation method. Researchers have interviewed at least 29 respondents consisting of principals, teachers, students, and parents. Researchers took primary documentation from school reports, from daily reports to semester reports.

The data analysis technique in this study used Miles and Huberman's theory. ${ }^{43}$ The first stage is data reduction. In this stage, the researchers summarize them according to the research topic, chooses important points, and focuses on important things. After the data is reduced, the next is the presentation of the data. The presentation of the data used is descriptive text so that it makes it easier for researchers to draw conclusions and the last stage is to draw conclusions.

\section{Finding and Discussion}

\section{Finding}

Based on the results and data analysis that has been carried out by the researchers, the findings of this study are:

The curriculum options in the new normal Covid-19 era in accordance with the

42 Ewan Ingleby, 'Research Methods in Education', Professional Development in Education, 2012 <https://doi.org/10.1080/19415257.2011.643130>.

43 Susan L. Morrow and Mary Lee Smith, 'Qualitative Research for Counseling Psychology', in Handbook of Counseling Psychology, 2000. 
recommendations of the Ministry of Education and Culture were implemented in ABA Pencongan Kindergarten, begin at the beginning of the new academic year 2020/2021.

Learning from home activities for early childhood can be a turning point for the role of the family because parents play a very important role in children's development because parents are the ones who interact a lot with children. Although the role of parents requires a higher intensity of patience because the learning situation is different from the learning that children usually experience at school. This finding was supported by the theory of Paulo Freire, which stated that the real learning process is not only in a formal environment such as school but also the environment and family as learning media for every child. The implementation of distance education for early childhood is in the form of assessment of development in the implementation of learning. Assessment of student learning in early childhood distance education includes checklists, anecdotal notes, and work to evaluate students' achievement.

Based on the results of observations and interviews that have been conducted by researchers regarding online learning methods via WhatsApp at ABA Pencongan Kindergarten, the learning process through WA in ABA Pencongan Kindergarten can be explained as follows. The online learning method through WhatsApp groups or called online services begins with the teacher first preparing the Daily Learning Implementation Plan which is compiled in the form of Learning From Home sheets, that the teacher will communicate to parents that learning is carried out online then the teacher will send the Learning file From Home to Parents. This Learning from Home Sheet contains worksheets that children will work on for 1 week, where the implementation of online learning is carried out 3 times in 1 week. The results of children's work can be in the form of sheets that have been done and then brought to school to be collected to the homeroom teacher of each child or can also be in the form of videos of children's activities doing activities from the Learning From Home sheet. In addition, there are also activity video tutorials in the form of directions from the teacher regarding the Learning from Home sheets that children will do at home.

The tasks given by the teacher during online learning during the Covid-19 pandemic at the ABA Pencongan Kindergarten are making media that contains several aspects of child development, habituation (memorization of short verses, iqra, hadist, and prayer), reading, singing, writing, coloring, drawing, and children's worksheets that have been submitted to parents. Learning is carried out by children accompanied by parents. Readiness for parents also has obstacles, including busy parents who find it difficult to divide their time in accompanying their children to study, children's emotional stability when faced with learning with their parents, and parents' ignorance and confusion in telling their children to do learning activities at home. All of these things become obstacles in general for parents who already have an android phone.

In the implementation of online learning, ABA Pencongan Kindergarten teachers must pay attention to time limits and reminders for students so that they are alert and attentive. Paying attention to online learning is needed so that they can easily adapt to this learning environment. The online learning program at ABA Pencongan Kindergarten is designed in such a way that it is creative, interactive, relevant, and student-centered. Teachers give plenty of time to develop effective strategies 
for delivering online instruction. Effective online instruction facilitates feedback from students, makes it easy for students to ask questions, think critically, and broaden students' learning horizons. Therefore, the implementation of online learning continues to make the relationship between teachers and students close even though they only meet by video calls and via instant messages or WhatsApp. The most important thing that is often considered by teachers at ABA Pencongan Kindergarten is evaluating the results of the learning process so that they can improve learning methods that are well accepted by children so that further learning can run optimally.

The supporting factors for early childhood distance education in the new normal Covid-19 era in ABA Pencongan Kindergarten can be explained in the following description: an institution (school) can apply simple learning and adjust the abilities of educators in implementing technology science, which can support the learning activities of educators easily and practically; Teachers have an important role in the distance education process applied to early childhood creatively and innovative learning with technology literate; the atmosphere of learning activities at home for students become more lively because in this condition children are very enthusiastic about learning at home, and parents can motivate children as well as learning assistance at home.

The inhibiting factors for early childhood distance education in the new normal Covid19 era in ABA Pencongan Kindergarten can be explained in the following description: the schools need to manage well their financial resources and continue to pay salaries for employees and teachers; the teachers have difficulty managing learning activities because they are required to unite the concentrations of students who are far apart; sometimes students do not focus on learning, they feel bored because in learning at home students are not like in school where they can freely interact with other people, and parents have a difficulty in fostering children's interest in learning.

\section{Discussion}

Learning in the Covid-19 New Normal Era

The corona virus disease or Covid-19 originated in the city of Wuhan, Hubei Province, China at the end of 2019. The source of infection was first reported related to the activity of the fish market in Wuhan which sells bats. The World Health Organization (WHO) or the world health agency officially announced on 11 February 2020 that this infectious disease is the Corona Virus Disease (Covid-19) caused by the Severe Acute Respiratory Syndrome Coronavirus-2 (SARS-CoV-2) virus. In humans, this corona virus causes respiratory infections such as SARS, MERS, as the same is true for Covid$19 .{ }^{44}$

The SARS-CoV-2 virus spreads from human to human through droplets or splashes of saliva that a person expels from the nose or mouth when sneezing, coughing, or even speaking. The first Covid-19 was reported in Indonesia on March 2, 2020, totaling two cases. March 31, 2020 data shows that there are 1,528 confirmed cases and 136 deaths. Covid-19 in Indonesia reached $8.9 \%$, this figure is the highest in Southeast Asia. ${ }^{45}$

Changes that occur in all aspects of life bring everyone to the new normal era or what

44 Kian Amboro, 'Kontekstualisasi Pandemi Covid-19 Dalam Pembelajaran Sejarah', Yupa: Historical Studies Journal, 2020 <https://doi.org/10.30872/yupa.v3i2.203>.

45 Adityo Susilo and others, 'Coronavirus Disease 2019: Tinjauan Literatur Terkini', Jurnal Penyakit Dalam Indonesia, 2020 <https://doi.org/10.7454/jpdi.v7i1.415>. 
is known as new life. New normal is a condition or social habit of the community or individual behavior that arises due to the long independent isolation of social life during the Covid-19 pandemic. ${ }^{46}$ So in the new normal era, there was a change in behavior to continue carrying out normal activities but added to implementing health protocols. All of this was done to prevent the transmission of Covid-19.

The application of the new normal concept is basically living by promoting a clean and healthy pattern or PHBS. This is in line with health protocols to prevent the corona virus. In other words, there must be a habit in your daily life to keep your distance from other people, using a mask and washing your hands until they are clean will become a new part of everyday life. To be able to apply a new normal life, people must be able to understand this concept properly. Thus, the subsistence of new normal life is related to adherence and discipline to health protocols. In a sense, this health protocol will be the key to starting a new normal life. ${ }^{47}$

Indonesians are now starting to carry out their daily activities as usual in Covid-19 time, in order to break the chain of transmission of Covid-19 and maintain student safety and health, especially early childhood, a number of PAUD institutions are implementing a Distance education system which that education system will continue well. Aspects of learning in the new normal era, namely:

\section{Active family participation}

When studying at home, family members must participate as learning facilitators. They can participate in providing guidance and

\footnotetext{
46 Adrian Habibi, 'Normal Baru Pasca Covid-19', Journal.Uinjkt.Ac.Id, 2020.

47 Erwin Agus Purwanto, Wahyudi Kumorotomo, and Ambar Widaningrum, 'Problematika Kebijakan Krisis Covid-19 Di Indonesia', Policy Brief, 2020 .
}

assistance so that the learning process of students becomes interesting. Of course, this requires the support of schools, which should train families to help children study at home.

\section{Shifting study space}

An important thing in the learning process is not in the teaching building or classroom. Now, learning is carried out at the homes of each student. The use of the internet makes it possible to create study spaces through personal devices without having to physically go somewhere.

\section{Individual and different learning}

Individual and different learning means that teaching each student must be done uniquely. The learning objectives of a group of learners may be the same, but individual circumstances may differ. Some learners may learn better by watching videos while others need to read books. For students, the opportunity to obtain learning materials to allocate learning resources at their homes can be a challenge.

\section{From exams to formative assessments}

Learning evaluation must be used to monitor the development of students, not to determine whether a student is capable or unable. $^{48}$

Analysis of the Implementation of Distance education in the Covid-19 New Normal Era

The first is planning, the preparation of learning planning is the first step in teaching activities to understand how to implement Distance education for early childhood in ABA Pencongan Kindergarten, Wiradesa District, Pekalongan Regency in the 2020-2021 academic year. In this case, the researcher will analyze Distance education planning for early childhood. The results of the analysis are as

48 Dian Arsa, Atmazaki Atmazaki, and Novia Juita, 'Literasi Awal Pada Anak Usia Dini Suku Anak Dalam Dharmasraya', Jurnal Obsesi: Jurnal Pendidikan Anak Usia Dini, 2019 <https://doi.org/10.31004/obsesi.v3i1.159>. 
follows: All activities begin with planning. The goal of the education force and the first step in planning is to set several types of goals. Purpose of starting the other components. Learning activities designed for children must meet the characteristics of children's needs, children's learning characteristics, and child development characteristics. The media and learning resources chosen must also be in accordance with the activities and be able to provide appropriate experiences for children. ${ }^{49}$

Thus, it can be analyzed that in $\mathrm{ABA}$ Pencongan Kindergarten, Wiradesa District, Pekalongan Regency, before carrying out distance education for early childhood, the teaching staff prepared a Learning Implementation Plan (RPP). The Learning Implementation Plan (RPP) is prepared by teachers in the Annual Program (PROTA) which is translated into a Semester Program (PROSEM), then translated again into a Weekly Lesson Preparation Plan (RPPM), and further translated into a Daily Learning Implementation Plan (RPPH). As the Ministry of Education and Culture recommends 3 curriculum implementation options for the new normal Covid-19 era, namely: a. Continue to use the 2013 national curriculum, b. Using emergency curriculum (in special conditions), c. To simplify the curriculum independently. ${ }^{50}$

Thus, it can be analyzed that in ABA Pencongan Kindergarten, Wiradesa District, Pekalongan Regency in the implementation of distance education for early childhood in the new normal era of Covid-19 using all curriculum options in the new normal Covid19 era in accordance with the recommendations of the Ministry of Education and Culture. The curriculum was implemented because it was to reduce the

49 Suryana.

50 Evy Mulyani, 'Inilah Perubahan Kebijakan Pendidikan Selama Masa Pandemi Covid-19', Sekretariat Kabinat Republik Indonesia, 2020. burden on teaching staff in implementing the national curriculum in the new normal Covid19 era.

The second is implementation, based on the results of the interview, it can be described that the implementation of distance education for early childhood at ABA Pencongan Kindergarten begins at the beginning of the new academic year 2020/2021. The solution provided in early childhood learning in the new normal Covid-19 era is by implementing distance education for early childhood involving parents through the use of the class Whatsapp group application.

This is in line with the provisions implemented by the Ministry of Education and Culture of the Republic of Indonesia which issued circular number 4 of 2020 concerning the implementation of educational education policies in the emergency period of the spread of the corona virus (Covid-19). Regarding the widespread spread of the corona virus disease (Covid-19), the physical and mental health of teachers, students, school principals, and all school members are the main considerations in implementing education policy. Related to this, the learning process is carried out through distance education. $^{51}$

Indeed, early childhood distance education is a challenge for teachers to be more creative and innovative in teaching. Teachers design learning, then parents must motivate their children to study at home. It is hoped that teaching and learning activities in the new normal Covid-19 era can continue well. This is supported by E. Mulyasa's theory which argues that to create creative and fun learning, skills are needed. Among them are learning skills or teaching skills. ${ }^{52}$

\footnotetext{
51 Mulyani.

52 Enco Mulyasa, 'Menjadi Guru Profesional
} Menciptakan Pembelajaran Kreatif Dan Menyenangkan', Bandung: Remaja Rosdakarya, 2011. 
Learning from home activities for early childhood can be a turning point for the role of the family because parents play a very important role in children's development because parents are the ones who interact a lot with children. This is a challenge for parents to go through. Of course, the role of parents requires a higher intensity of patience because the learning situation is different from the learning that children usually experience at school.

This is supported by the theory of Paulo Freire, a world education expert, which states that the real learning process is not only in a formal environment such as school but also the environment and family as learning media for every child. Good education is the key to success so that children grow into quality children. This is determined by the level of seriousness of the parents in planning their children's education and the time spent on their children. ${ }^{53}$

The third is evaluation. Evaluation is an act of a process to determine the value of something. In the assessment process, there are several things that must be considered, namely the assessment must refer to the indicators that will be achieved as programmed in the lesson plan. The results of the assessment are then summarized in the student development assessment format. ${ }^{54}$ Ways to conduct assessments in early

\footnotetext{
53 Engelbertus Nggalu; Fakhruddin Bali Fakhruddin; Rifa'i, Achmad, 'PENGEMBANGAN MODEL PEMBELAJARAN INDUKTIF KATA BERGAMBAR UNTUK PENGENALAN KEMAMPUAN LITERASI DINI AUD', Journal of Primary Education, Vol 5 No 2 (2016), 2016, $120-29$

$<$ https://journal.unnes.ac.id/sju/index.php/jpe/article /view/12902>.

54 Rini Asnawati Dwi Maisari, Gimin Suyadi, 'Pengaruh Model Pembelajaran Koperatif Tipe Make a Match Terhadap Pemahaman Konsep Matematis (Studi Pada Siswa Kelas VIII Semester Ganjil SMPN 5 Bandar Lampung Tahun Pelajaran 2012/2013)', 2.1 (2013), 1-6.
}

childhood include: a. Checklist, contains progress achievement indicators that have been set in the daily lesson plan; b. Anecdotal notes, anecdote notes are used to record all the facts, tell the situation that happened, what the child did and said; c. Masterpiece, children's thoughts that are expressed in the form of real works can be in the form of handwork, artwork, or children's displays, for example, pictures, paintings, folds, collages, and cutouts. ${ }^{55}$

So thus it can be analyzed that the implementation of distance education for early childhood is in the form of assessment of development in the implementation of learning. Assessment of student learning includes (checklists, anecdotal notes, and work) to evaluate students' achievement in early childhood distance education.

Analysis of Supporting and Inbibiting Factors for Distance education in the Covid-19 New Normal Era

In the implementation of distance education for early childhood in the new normal Covid-19 era at ABA Pencongan Kindergarten, Wiradesa District, Pekalongan Regency, there are supporting and inhibiting factors for certain parties involved in the process, namely school institutions as organizers, teachers as teachers at schools, students as objects in learning and parents as guides in learning students at home. ${ }^{56}$

The supporting factors for early childhood Distance education in the new normal Covid-19 era at ABA Pencongan

55 Erni Munastiwi, 'Manajemen Ekstrakurikuler Pendidikan Anak Usia Dini (PAUD)', MANAGERIA: Jurnal Manajemen Pendidikan Islam, 2019 <https://doi.org/10.14421/manageria.2018.32-09>.

${ }^{56}$ Harold Alderman and others, 'Evidence of Impact of Interventions on Growth and Development during Early and Middle Childhood', in Disease Control Priorities, Third Edition (Volume 8): Child and Adolescent Health and Development, 2017 <https://doi.org/10.1596/978-1-4648-0423-6_ch7>. 
Kindergarten, Wiradesa District, Pekalongan Regency, are as follows:

\section{For School Institutions}

In early childhood distance education, institutions can apply simple learning and adjust the abilities of teachers in implementing technology science. It is hoped that the use of smartphones and internet networks can support the learning activities of teachers easily and practically.

\section{For Teachers}

Teachers have an important role in the distance education process applied to early childhood. Teachers will learn more about media or applications in teaching. Therefore, teachers will be technology literate so that they are able to create creative and innovative learning.

For Students

This feeling of pleasure is what makes students a supporting factor in early childhood distance education activities. Emotional students who can be well-conditioned can make the atmosphere of learning activities at home even more lively because in this condition children are very enthusiastic about learning at home.

For Parents

Parents can motivate children in the form of support as well as learning assistance at home. Because children need motivation from the people closest to them, especially parents as the first environment for children. Therefore, in implementing distance education, early childhood really needs the involvement of parents in children's learning at home.

Furthermore, the inhibiting factors for early childhood distance education in the new normal Covid-19 era at ABA Pencongan Kindergarten, Wiradesa District, Pekalongan Regency, are as follows:

For School Institutions
Parents of students began to worry about having to pay tuition fees or monthly infaq fees because the absence of children from school meant that the daily routine burden of the school was reduced. Even though schools also need to continue to manage their financial resources and continue to pay salaries for employees and teachers.

For Teachers

When learning face-to-face, teachers are accustomed to organizing learning. However, the problem is when early childhood learning takes place remotely. Teachers have difficulty managing learning activities because teachers are required to unite the perceptions and concentrations of students who are far apart.

For Students

During early childhood distance education activities students carry out learning activities at home with parents. Sometimes students feel bored and bored because in learning at home students are not like in school where they can freely interact with other people. So that it will affect the concentration of students so that they do not focus on learning.

For Parents

The current early childhood distance education system that is being implemented has received complaints from parents of students. Starting from the limit on the internet network or quota, the limited time for parents to assist children, and the difficulty in fostering children's interest in learning.

\section{Conclusion}

The results showed the implementation of Distance education for early childhood in the new normal Covid-19 era in ABA Pencongan Kindergarten through the class of Whatsapp (WA) group. The online learning method through WhatsApp groups or called online services begins with the teacher first 
preparing the daily learning implementation plan which is compiled in the form of learning from home sheets, that the teacher will communicate to parents that learning is carried out online then the teacher will send the learning file from home to parents. The tasks given by the teacher during online learning during the COVID-19 pandemic at the ABA Pencongan Kindergarten are making media that contains several aspects of child development, habituation (memorization of short verses, iqra, hadist, and prayer), reading, singing, writing, coloring, drawing, and children's worksheets that have been submitted to parents. Factors that support this learning process are adequate school facilities, the skills of educators in using media or applications in qualified teaching, good psychological conditions for students, and free time for parents to assist and guide students' learning at home. While the inhibiting factors are school financial constraints, difficulties for teachers in managing learning activities, students being forced to make academic adjustments by limiting social interaction, and the busyness of some parents, and additional costs for buying internet data packages.

Based on the conclusions that have been described, the suggestions that can be recommended by the researcher are as follows: To the headmaster of ABA Pencongan Kindergarten, Wiradesa District, Pekalongan Regency, with a decision that requires teachers and students to learn from home, the principal must be able to quickly and accurately convey the spirit of change to teachers, students and parents; To the teachers of ABA Pencongan Kindergarten, Wiradesa District, Pekalongan Regency in implementing Distance education for early childhood in the new normal Covid19 era, the teachers sometimes make video calls with students once a week by implementing collaboration with parents, so that students are more establish interactions with students; Parents are expected to be aware of the importance of education from their families and parents should be more active in communicating with teachers through the class of Whatsapp group; and to students, remain enthusiastic about learning at home with their father or mother.

\section{References}

\section{Journal}

Alderman, Harold, Jere R. Behrman, Paul Glewwe, Lia Fernald, and Susan Walker, 'Evidence of Impact of Interventions on Growth and Development during Early and Middle Childhood', in Disease Control Priorities, Third Edition (Volume 8): Child and Adolescent Health and Development, 2017 <https://doi.org/10.1596/978-14648-0423-6_ch7>

Alfina, Alisa, and Rosyida Nurul Anwar, 'Manajemen Sekolah Ramah Anak Paud Inklusi', Al-Tanzim: Jurnal Manajemen Pendidikan Islam, 2020 $<$ https://doi.org/10.33650/altanzim.v4i1.975>

Amboro, Kian, 'Kontekstualisasi Pandemi Covid-19 Dalam Pembelajaran Sejarah', Yupa: Historical Studies Journal, 2020 $<$ https://doi.org/10.30872/yupa.v3i2.2 $03>$

Areba, George Ngwacho, 'Covid-19 Pandemic Impact on Kenyan Education Sector: Learner Challenges and Mitigations', Journal of Research Innovation and Implications in Education, 2020

Arsa, Dian, Atmazaki Atmazaki, and Novia Juita, 'Literasi Awal Pada Anak Usia Dini Suku Anak Dalam Dharmasraya', Jurnal Obsesi: Jurnal Pendidikan Anak Usia Dini,

<https://doi.org/10.31004/obsesi.v3i1. 159>

Bali Fakhruddin; Rifa'i, Achmad, Engelbertus Nggalu; Fakhruddin, 'Pengembangan Model Pembelajaran Induktif Kata Bergambar Untuk Pengenalan Kemampuan Literasi Dini Aud', Journal 
of Primary Education, Vol 5 No 2 (2016), 2016, 120-29 $<$ https://journal.unnes.ac.id/sju/index. $\mathrm{php} / \mathrm{jpe} /$ article/view/12902>

Catalano, Amy J., Bruce Torff, and Kevin S. Anderson, 'Transitioning to Online Learning during the COVID-19 Pandemic: Differences in Access and Participation among Students in Disadvantaged School Districts', International Journal of Information and Learning Technology, $38.2 \quad$ (2021) $<$ https://doi.org/10.1108/IJILT-062020-0111>

Dwi Maisari, Gimin Suyadi, Rini Asnawati, 'Pengaruh Model Pembelajaran Koperatif Tipe Make a Match Terhadap Pemahaman Konsep Matematis (Studi Pada Siswa Kelas VIII Semester Ganjil SMPN 5 Bandar Lampung Tahun Pelajaran 2012/2013)', 2.1 (2013), 1-6

Evridawati, Beryana, Yufiarti, and Elindra Yetti, 'The Cognitive Style and Attachment on Early Childhood Speech Skills', JPUD - Jurnal Pendidikan Usia Dini, 2020 <https://doi.org/10.21009/jpud.141.03 $>$

Friedman, Joseph, Hunter York, Ali H. Mokdad, and Emmanuela Gakidou, 'U.S. Children "Learning Online" during COVID-19 without the Internet or a Computer: Visualizing the Gradient by Race/Ethnicity and Parental Educational Attainment', Socius, 7 (2021) $<$ https://doi.org/10.1177/23780231219 92607>

Habibi, Adrian, 'Normal Baru Pasca Covid19', Journal.Uinjkt.Ac.Id, 2020

Hamid, Mustofa Abi, Lely Yuliawati, and Didik Aribowo, 'Feasibility of Electromechanical Basic Work EModule as a New Learning Media for Vocational Students', Journal of Education and Learning (EduLearm), 2020 <https://doi.org/10.11591/edulearn.v1 4i2.15923>

Handayani, Diah, 'Penyakit Virus Corona 2019’, Jurnal Respirologi Indonesia, 2020
Harper, Kimberly C., Kuanchin Chen, and David C. Yen, 'Distance Learning, Virtual Classrooms, and Teaching Pedagogy in the Internet Environment', Technology in Society, 2004 <https://doi.org/10.1016/j.techsoc.200 4.08.002>

Hermanto, Ni Gusti Made Rai, and Arfan Fahmi, 'Students' Opinions about Studying from Home during the Covid19 Pandemic in Indonesia', Cypriot Journal of Educational Sciences, 16.2 (2021) <https://doi.org/10.18844/CJES.V16I 2.5627>

Iftitah, Selfi Lailiyatul, 'Strategi Pengembangan Nilai-Nilai Keagamaan Pada Anak Usia Dini Di TK Islamic Center Surabaya', Kindergarten: Journal of Islamic Early Childhood Education, 2020 <https://doi.org/10.24014/kjiece.v3i1. 9407>

Imania, Kuntum Annisa, and Siti Khusnul Bariah, 'Rancangan Pengembangan Instrumen Penilaian Pembelajaran Berbasis Daring', Jurnal Petik, 2019 $<$ https://doi.org/10.31980/jpetik.v5i1.4 45>

Indriyani, Erlina Neni, 'Pengaruh Korelasi Peran Orang Tua Dan Guru Berbasis Online Di Rumah Dalam Pembelajaran Pendidikan Agama Islam', Jurnal Pendidikan Guru, $2.1 \quad$ (2021) $<$ https://doi.org/10.47783/jurpendigu. v2i1.185>

Ingleby, Ewan, 'Research Methods in Education', Professional Development in Education, 2012 <https://doi.org/10.1080/19415257.20 11.643130>

Kim, Ji Young, and Daniel M. Fienup, 'Increasing Access to Online Learning for Students With Disabilities During the Covid-19 Pandemic', Journal of Special Education, 2021 <https://doi.org/10.1177/00224669219 98067>

Kim, Jinyoung, 'Learning and Teaching Online During Covid-19: Experiences of Student Teachers in an Early Childhood Education Practicum', 
International Journal of Early Childhood, $2020<$ https://doi.org/10.1007/s13158020-00272-6>

Krogh, Suzanne L., Pamela Morehouse, Suzanne L. Krogh, and Pamela Morehouse, 'Inquiry-Based Learning', in The Early Childhood Curriculum, 2020 $<$ https://doi.org/10.4324/97804292807 64-6>

Mulyani, Evy, 'Inilah Perubahan Kebijakan Pendidikan Selama Masa Pandemi Covid-19', Sekeretariat Kabinat Republik. Indonesia, 2020

Mulyasa, E., and Mulyasa.H.E., Manajemen Paud, Manajemen PAUD, 2014

Mulyasa, Enco, 'Menjadi Guru Profesional Menciptakan Pembelajaran Kreatif Dan Menyenangkan', Bandung: Remaja Rosdakarya, 2011

Munastiwi, Erni, 'Manajemen Ekstrakurikuler Pendidikan Anak Usia Dini (PAUD)', Manageria: Jurnal Manajemen Pendidikan Islam, 2019 $<$ https://doi.org/10.14421/manageria.2 018.32-09>

Oktaria, Renti, and Purwanto Putra, 'Pendidikan Anak Dalam Keluarga Sebagai Strategi Pendidikan Anak Usia Dini Saat Pandemi Covid-19', Jurnal Ilmiah Pesona PAUD, 2020 <https://doi.org/10.24036/108806>

Pashler, Harold, Mark McDaniel, Doug Rohrer, and Robert Bjork, 'Learning Styles Concepts and Evidence', Psychological Science in the Public Interest, Supplement, 2008 $<$ https://doi.org/10.1111/j.15396053.2009.01038.x>

Purwanto, Agus, Rudy Pramono, Masduki Asbari, Priyono Budi Santoso, Laksmi Mayesti Wijayanti, Choi Chi Hyun, and others, 'Universitas Muhammadiyah Enrekang Studi Eksploratif Dampak Pandemi Covid-19 Terhadap Proses Pembelajaran Online Di Sekolah Dasar', EduPsyCouns: Journal of Education, Psychology and Counseling, 2020

Purwanto, Erwin Agus, Wahyudi Kumorotomo, and Ambar Widaningrum, 'Problematika Kebijakan
Krisis Covid-19 Di Indonesia', Policy Brief, 2020

'Revitalization of Education for Children in Indonesian Families During the Covid19 Pandemic', Illkögrretim Online, 20.3 (2021)

<https://doi.org/10.17051/ilkonline.20 21.03.48>

Rifa'i, Ilyas, Ferli Septi Irwansyah, Mar'tus Sholihah, and Astri Yuliawati, 'Dampak Dan Pencegahan Wabah Covid-19: Perspektif Sains Dan Islam', Jurnal Pendidikan, 2020

Rohmadani, Adinda Icha, 'Dampak Covid 19 Terhadap Cara Berpikir Dalam Pembelajaran Daring: Studi Kasus Di Yogyakarta', Edification Journal, 2020 $<$ https://doi.org/10.37092/ej.v3i1.224 $>$

Rohman, M. Ghofar, and Purnomo Hadi Susilo, 'Peran Guru dalam Penggunaan Media Pembelajaran Berbasis Teknologi Informasi dan Komunikasi (TIK) Studi Kasus di Tk Muslimat $\mathrm{Nu}$ Maslakul Huda', JURNAL REFORMA, 2019 $<$ https://doi.org/10.30736/rfma.v8i1.1 $40>$

Saifulloh, Ahmad Munir, and Mohammad Darwis, 'Manajemen Pembelajaran Dalam Meningkatkan Efektivitas Proses Belajar Mengajar Di Masa Pandemi Covid-19', Bidayatuna: Jurnal Pendidikan Guru Mandrasah Ibtidaiyah, 2020 $<$ https://doi.org/10.36835/bidayatuna. v3i2.638>

Singh, Vandana, and Alexander Thurman, 'How Many Ways Can We Define Online Learning? A Systematic Literature Review of Definitions of Online Learning (1988-2018)', American Journal of Distance Education, 2019 <https://doi.org/10.1080/08923647.20 $19.1663082>$

Suraya, Asep, Hendri Hermawan, and Iain Pekalongan, 'Progressive Education in Indonesia: Insight from Soedjatmoko Thought', 7.2 (2020), 113-21 <https://doi.org/10.32923/tarbawy.v7i $2.1410>$

Susilo, Adityo, Cleopas Martin Rumende, 
Ceva Wicaksono Pitoyo, Widayat Djoko Santoso, Mira Yulianti, Herikurniawan Herikurniawan, and others, 'Coronavirus Disease 2019: Tinjauan Literatur Terkini', Jurnal Penyakit Dalam Indonesia, 2020

<https://doi.org/10.7454/jpdi.v7i1.415 $>$

Utami, Tri, 'Penanaman Kompetensi Inti Melalui Pendekatan Saintifik di PAUD Terpadu An-Nur', Yaa Bunayya (Jurnal Pendidikan Anak Usia Dini), 2017

Wind, William M., Richard M. Schwend, and Judy Larson, 'Sports for the Physically Challenged Child.', The Journal of the American Academy of Orthopaedic Surgeons, 2004

$<$ https://doi.org/10.5435/00124635200403000-00008>

Yoon, Bogum, 'English Language Learners' Language and Literacy Development: A Brief Synopsis of Major Theoretical Orientations for Middle School Teachers', Middle School Journal, 52.1 (2021) $<$ https://doi.org/10.1080/00940771.20 $20.1840270>$
Pembelajaran Daring Dalam Revolusi Industri 4.0', Sainteks 2019, 2019

Mohamedbhai, Goolam, 'COVID-19: What Consequences for Higher Education', University World News, 2020

Morrow, Susan L., and Mary Lee Smith, 'Qualitative Research for Counseling Psychology', in Handbook of Counseling Psychology, 2000

M Fadlillah, Bermain \& Permainan Anak Usia Dini, Pranadamedia Grub, 2019

\section{Online References}

Anwar Makarim, Nadiem, 'Pelaksanaan Kebijakan Pendidikan Dalam Masa Darurat Penyebaran Covid -19', Surat Edaran Permendikbud No 4 Tabun 2020, 2020

RI, Kemenkes, 'Corona Virus Disease 2019', Peraturan Menteri Kesehatan Republik Indonesia, 2020

Trahern Jones of Pediatric Infectious Diseases Instructor of Pediatrics of Utah Health Lake, City, and Francisco Danielle Nahal Resident Physician Medical Center, 'Beating the Pandemic: What Emergency Providers Should Know About COVID-19', Pediatric Emergency Medicine Reports, 2020

'Undang Undang Republik Indonesia Nomor 20 Tahun 2003', Kemenristekdikti, 2003

\section{Books}

Alaby, Muhammad Awin, 'Media Sosial Whatsapp Sebagai Media Pembelajaran Jarak Jauh Mata Kuliah Ilmu Sosial Budaya Dasar (ISBD)', Ganaya: Jurnal Ilmu Sosial Dan Humaniora, 2020

Suryana, D., 'Pendidikan Anak Usia Dini Stimulasi Dan Aspek Perkembangan Anak.', Kencana., 2016

Andrianto Pangondian, Roman, Paulus Insap Santosa, and Eko Nugroho, 'Faktor Faktor Yang Mempengaruhi Kesuksesan 